\title{
Influence of Age-Specific Mortality on the Life History Traits of Two Estuarine Copepods*
}

\author{
Darcy J. Lonsdale** \\ University of Maryland, Center for Environmental and Estuarine Studies, Chesapeake Biological Laboratory, Solomons, \\ Maryland 20688, USA
}

\begin{abstract}
Life history traits - including day of first reproduction, lifetime reproductive output, and total lifespan - were determined in the laboratory for 2 estuarine copepods: Scottolana canadensis (Willey) and Oithona colcarva Bowman. The day of first reproduction was earlier for $O$. colcarva than for $S$. canadensis, but the latter had a much longer reproductive lifespan and a greater reproductive output in terms of nauplii produced per female. The copepods exhibited intrinsic rates of increase ranging from $0.01-0.19 \mathrm{~d}^{-1}$ for $O$. colcarva $\left(15^{\circ}-25^{\circ} \mathrm{C}\right)$ and $0.05-0.15 \mathrm{~d}{ }^{\prime}$ for $\mathrm{S}$. canadensis $\left(20^{\circ}-25^{\circ} \mathrm{C}\right)$. A comparison of life history traits of $\mathrm{S}$. canadensis and $O$. colcarva with the copepod Acartia tonsa Dana revealed differences which may reflect variation in age-specific patterns in mortality of the field populations. For $S$. canadensis, juvenile mortality (specifically of planktonic nauplii) may be higher and more variable than mortality of epibenthic adults. In contrast, mortality of planktonic $A$. tonsa adults may be high and more variable relative to their juvenile stages. The reproductive strategy of $S$. canadensis is characterized by a later day of first reproduction, more discrete egg production, and a longer lifespan compared to $A$. tonsa. Life history traits and variable age-specific mortality patterns of these species are consistent with current theory which predicts that variation in age-specific mortality acts as a selective force on the reproductive patterns of organisms.
\end{abstract}

\section{INTRODUCTION}

Current life history theory is based on the assumption that the evolution of a particular combination of reproductive traits or tactics proceeds towards increasing the fitness of the organism within the constraints of its environment (Stearns, 1976). Such tactics may reflect a compromise between predation, competition, coping with physical factors, and the ability to reproduce (Gadgil and Bossert, 1970; Pianka and Parker, 1975). Correlative studies of lifecycle characteristics with environmental conditions of both marine and freshwater zooplankton have resulted in some thought-provoking hypotheses regarding the adaptive value of such traits. For example, it has been proposed that when food resources are scarce, vertical migration to colder waters, resulting in delayed development of

\footnotetext{
- Contribution No. 1142 of the University of Maryland's Center for Environmental and Estuarine Studies

- Address effective December 1980: Ecology and Evolution Department, Graduate Biology, State University of New York at Stony Brook, Stony Brook, New York 11794, USA
}

some marine zooplankton, may ultimately result in an overall increase in fecundity and survival of offspring (McLaren, 1963, 1974). Life history traits also have been suggested to explain biogeographical trends between planktonic taxa (Allan, 1976). In general however, the lack of an adequate data base has meant that these theories are largely untested.

This paper addresses the contentions that agespecific variation in mortality may be an important selective force on the fitness-optimizing strategy of an organism (Murphy, 1968; Charnov and Schaffer, 1973) and that in particular where juvenile mortality is more variable than mortality of adults, smaller clutches and a longer lifespan will be favored (Schaffer, 1974).

Two estuarine copepods were chosen for laboratory determination of general life history traits: the epibenthic harpacticoid Scottolana canadensis (Willey) and the planktonic cyclopoid Oithona colcarva Bowman. They are seasonal species in Chesapeake Bay and usually occur in lower densities than the planktonic calanoid Acartia tonsa Dana. Specific predictions can be made concerning differences and similarities in the life history traits of the three species based on data 
concerning the natural sources of mortality to nauplii and adults. The nauplii of $S$. canadensis are more susceptible to variable sources of predation than adults whereas $A$. tonsa adults may have the greater risk (Lonsdale, 1981).

\section{METHODS AND MATERIALS}

Investigation of the survivorship and fecundity schedules of a species provides the relevant statistics which, according to life history theory, will reflect differences in age-specific mortality (Schaffer, 1974). It also allows determination of the intrinsic rate of population increase $(r)$ which could reflect significant differences in reproductive strategies between species (MacArthur, 1972; Allan, 1976). To obtain these data, Scottolana canadensis and Oithona colcarva nauplii and adults were collected in plankton tows using a 63$\mu \mathrm{m}$ mesh net at the pier of the Chesapeake Biological Laboratory, placed in 2-1 Erlenmeyer flasks with filtered ambient (Whatman Glass Fiber ' $\mathrm{C}$ ') Bay water and kept at $20^{\circ} \mathrm{C}$ in an environmental box. To reduce the likelihood of inbreeding and to maintain genetic variability, copepod populations from different flasks were mixed every month, and new individuals from the field were added occasionally.

The copepods were fed a mixture of algae, Prorocentrum marieae-lebouriae variety and Pseudoisochrysis sp. (VA-12) approximately 2-3 times a week. Rotifers and ciliates which grew in the cultures usually were not removed.

\section{Scottolana canadensis Life History Experiments}

To allow for acclimation to test conditions, Scottolana canadensis copepods were placed in flasks containing 10,15 or $20 \%$ S Millipore-filtered (MP-filtered; $0.45 \mu \mathrm{m})$ water and held at either $15^{\circ}, 20^{\circ}$ or $25^{\circ} \mathrm{C}$ for 2 weeks prior to the beginning of life tables experiments. The experimental water was made from ambient Bay water combined with high-salinity seawater $(31.5 \%$ S) obtained from the Delaware coast or with distilled water.

An algal mixture consisting of a $1: 2$ ratio of Prorocentrummarieae-lebouriae: Pseudoisochrysis sp. (VA-12) was used as the food source. The algae was grown in culture using Provasoli's $1 / 2$ strength E.S. media (James, 1973 ) at $15 \% \mathrm{~S}$ and $15^{\circ} \mathrm{C}$ on a $14: 10 \mathrm{~h}$ light-dark cycle. Algal growth was maintained by adding fresh media to the cultures once a week. Experimental algal mixtures used to feed the copepods were prepared 2-3 times a week by combining $200 \mathrm{ml}$ of the algal mixture with $100 \mathrm{ml}$ of either distilled,
$15 \%$ or $30 \% \mathrm{~S}$ (MP-filtered; $0.45 \mu \mathrm{m}$ ) water. Cell numbers usually were counted once a week on an electronic particle counter (Particle Data, Inc.).

Fifteen mating pairs of Scottolana canadensis were placed in covered $50-\mathrm{ml}$ Stendor dishes with $20 \mathrm{ml}$ of MP-filtered $(0.45 \mu \mathrm{m})$ adjusted Bay water at the appropriate temperature $(25$ pairs were used for the experiments conducted at $15 \% \mathrm{~S}$ and $20^{\circ} \mathrm{C}$ and at all salinities at $15^{\circ} \mathrm{C}$ ). Experiments were conducted in environmental boxes with a 12:12 h light-dark cycle. Each pair was fed $1 \mathrm{ml}$ of the algal mixture daily for the duration of the experiments although females which lived beyond 2 months were sometimes fed $2 \mathrm{ml}$ every other day. Experimental dishes were washed and the water changed once a week. The weekly initial quantity of algal food in both series of life table experiments, including Oithona colcarva, was always in excess of that normally encountered by zooplankton in the Chesapeake Bay; $1.0-1.310^{7} \mu^{3} \mathrm{ml}^{-1}$ (Richman et al., 1977).

The mating pairs were observed daily; when a

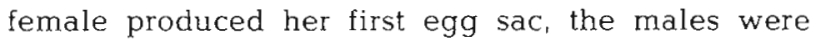
removed. Females were placed in another dish when the nauplii hatched, and total numbers and day of hatching were recorded. Survival, development time to mature female and sex were determined for each brood. These statistics also were recorded for all subsequent broods and the survival of the original females was determined. Females were followed until all had discontinued egg production for 2 weeks or until Day 100. The survivorship data from all nauplii were combined and the time at which $50 \%$ of the female copepodites became mature was determined (as evidenced by the formation of mating pairs or the appearance of ovaries). Data from the 2 schedules were combined by considering the day at which $50 \%$ of the females matured equivalent to the first day of observations on the mating pairs.

\section{Oithona colcarva Life History Experiments}

Adult Oithona colcarva were removed from culture and placed in $120-\mathrm{m}$ ] watch glasses at 10,15 or $20 \% \mathrm{~S}$ and $15^{\circ}, 20^{\circ}$ and $25^{\circ} \mathrm{C}$. The females were observed daily and removed to another dish as they became gravid. Approximately 10-15 newly hatched nauplii from these females were placed in a $50-\mathrm{ml}$ covered Stendor dish and maintained under the different physical regimes. Ten to 15 dishes of nauplii were monitored. They were cultured and observed using the same schedule as for Scottolana canadensis, except that a third algal species Isochrysis galbana was added to the food mixture. Prior experimentation had revealed that less than $10 \%$ of the newly hatched 
nauplii survived beyond the second or third day unless this alga was present.

The nauplii were observed daily and monitored until they became gravid females. If both males and females appeared in one dish, the females were observed for survivorship and fecundity statistics. The appearance of ovaries and any unfertile eggs was noted.

Due to the skewed sex ratio observed in Oithona (5.3 o $q: 1$ f) and to indications that one mating may not be sufficient throughout the reproductive life of female $O$. colcarva, it was necessary to conduct a second series of experiments to obtain adequate adult survivorship and fecundity information. Nauplii were placed in 1-1 beakers under the appropriate physical conditions and fed in excess daily. Approximately 25-30 copepodites (CIV) were placed in $120-\mathrm{ml}$ covered watch glasses with 2 or 3 males and fed daily. As females became gravid they were placed in Stendor dishes. The day and number of nauplii which hatched were recorded. On that day, the female was returned to the large watch glass containing the males. Thus, it was not possible to follow the survivorship of successive broods as done with Scottolana canadensis. Data from the 2 schedules were combined by considering the hatching of the first fertile brood from the nauplius survivorship experiments equivalent to that of the first brood in the adult survivorship and fecundity experiments.

The instantaneous rate of population increase $(r)$ for both Scottolana canadensis and Oithona colcarva was calculated from the following (Birch, 1948):

$$
1=\Sigma l_{x} m_{x} e^{-r x}
$$

where $x_{x}=$ probability of surviving to age $x_{i}$ $m_{x}=$ number of female NI per female aged $x$, hatched during the interval of $x$ to $x+1 ; r=$ instantaneous rate of population increase $\left(\mathrm{d}^{-1}\right) ; \mathrm{x}=$ age in days from $\mathrm{NI}$.

\section{RESULTS}

\section{Scottolana canadensis: Survivorship and Reproduc- tion}

The survivorship schedule $\left(l_{x}\right)$ of Scottolana canadensis nauplii from day of hatching (Day 0) through adult was determined at $20^{\circ}$ and $25^{\circ} \mathrm{C}$ but was not obtained at $15^{\circ} \mathrm{C}$ as no young were produced at that temperature (Fig. 1). Although the survivorship of all nauplii from the first through the last broods was combined in the survivorship schedule, survivorship of later broods (8-13) appeared to be less than that of earlier broods (1-7) (Fig. 2). The development time from NI to CI was approximately half the time from CI to CVI (Table 1).

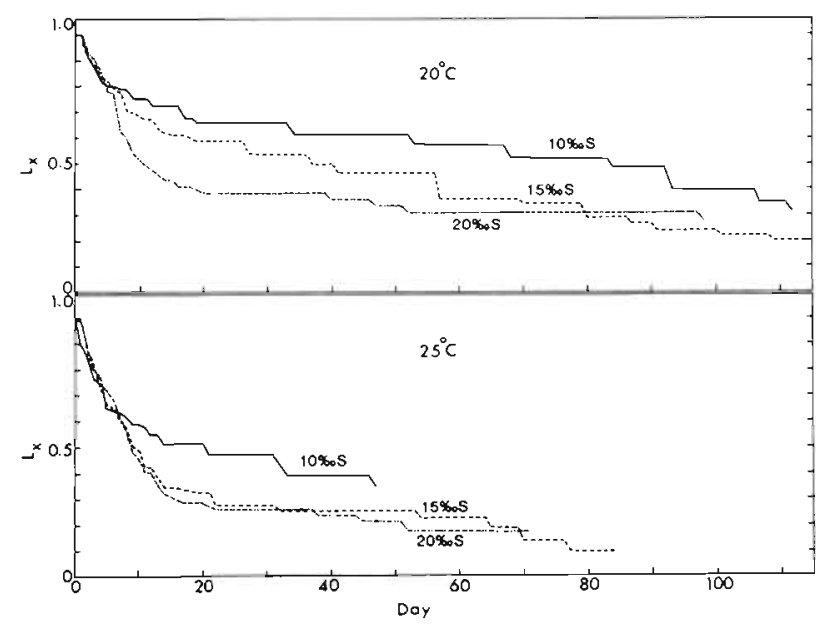

Fig. 1. Scottolana canadensis. Survival in the laboratory from day of hatching through reproductive-female stage, at $20^{\circ}$ and $25^{\circ} \mathrm{C}$ and in 3 different salinities. $L x=$ probability of surviving to age $x$

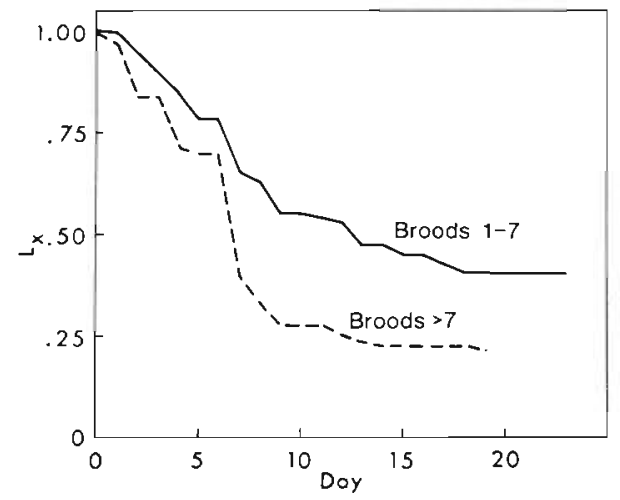

Fig. 2. Scottolana canadensis. Survival of nauplii hatching from early compared to later-produced broods. $L x=$ probability of surviving to age $x$

Salinity and temperature influenced the rate of instar survival in Scottolana canadensis (Fig. 1). Survivorship was greater at the lowest salinity $(10 \% \mathrm{~S})$ and temperature $\left(20^{\circ} \mathrm{C}\right)$. This influence of temperature may have been an experimental artifact. It appeared that a small proportion of laboratory mortality for nauplii and copepodites (CI-III) at $25^{\circ} \mathrm{C}$ was caused by entrapment in the surface tension of the water. This problem did not appear to be important at $20^{\circ} \mathrm{C}$. These observations are supported by results obtained by D. R. Heinle (unpubl.) who found higher survival of $S$. canadensis nauplii at $25^{\circ}-30^{\circ} \mathrm{C}(0.83$ on Day 6) in containers which had a much reduced surface area. However, the survival of nauplii at $20^{\circ} \mathrm{C}$ was greater in my experiments despite the larger surface area.

The mean day of first reproduction of Scottolana canadensis was 25.3 at $20^{\circ} \mathrm{C}$ and 16.3 at $25^{\circ} \mathrm{C}$. Reproduction continued after $100 \mathrm{~d}$ with females held at 
Table 1. Scottolana canadensis and Oithona colcarva. Mean and standard deviation of development time (d) of naupliar and copepodite stages at 3 temperatures

\begin{tabular}{|c|c|c|c|c|c|c|c|c|c|c|}
\hline \multirow{3}{*}{$\begin{array}{l}\text { Temperature } \\
\text { ('C) }\end{array}$} & \multicolumn{4}{|c|}{ Scottolana canadensis } & \multicolumn{6}{|c|}{ Oithona colcarva } \\
\hline & \multicolumn{2}{|c|}{$\mathrm{NI}-\mathrm{Cl}$} & \multirow[t]{2}{*}{$\mathrm{CI}-\mathrm{VI}{ }^{\bullet}$} & \multicolumn{2}{|c|}{$\begin{array}{c}\text { Days to } \\
50 \% \text { adults }\end{array}$} & \multicolumn{2}{|c|}{$\mathrm{NI}-\mathrm{CI}$} & \multirow[t]{2}{*}{$\mathrm{CI}-\mathrm{VI} \cdot$} & \multicolumn{2}{|c|}{$\begin{array}{c}\text { Days to } \\
50 \% \text { adults }\end{array}$} \\
\hline & $\bar{x}$ & S.D. & & $\bar{x}$ & S.D. & $\bar{x}$ & S.D. & & $\bar{x}$ & S.D. \\
\hline 15 & - & - & - & - & - & 13.8 & 1.2 & 12.2 & 26.0 & 0.0 \\
\hline 20 & 4.9 & 1.1 & 10.1 & 15.0 & 1.6 & 8.1 & 1.1 & 9.0 & 17.1 & 1.1 \\
\hline 25 & 3.9 & 0.9 & 8.1 & $12.0^{\cdots}$ & 1.4 & 5.6 & 1.1 & 5.4 & 11.0 & 1.9 \\
\hline \multicolumn{11}{|c|}{$\begin{array}{l}\text { Development time from CI-CVI was determined by subtraction of development time of } \mathrm{NI}-\mathrm{CI} \text { from total time to adult } \\
\text { - } 12.0 \mathrm{~d} \text { for development to reproductive adult may be an overestimate due to inadequate food resources for copepodite } \\
\text { (McLaren, 1978) or to higher salinities. Harris (1977) found this time to be approximately } 7 \mathrm{~d}, 25^{\circ} \mathrm{C} \text { and } 10 \% \mathrm{~S} \text {, while unde } \\
\text { the same physical conditions I found it took } 10 \mathrm{~d} \text { for } 50 \% \text { of the females to reach the adult stage. The data at } 20^{\circ} \mathrm{C} \text { are } \\
\text { consistent with Harris }\end{array}$} \\
\hline
\end{tabular}

$20^{\circ} \mathrm{C}$, while it ceased after approximately $80 \mathrm{~d}$ at $25^{\circ} \mathrm{C}$. Female copepods held at $15^{\circ} \mathrm{C}$ for $100 \mathrm{~d}$ never produced a viable brood. When they were moved to $20^{\circ} \mathrm{C}$ for $2 \mathrm{~d}$, several clutches of eggs were produced which resulted in viable nauplii. Moreover, this occurred without the reintroduction of a male. This suggests a mechanism by which overwintering copepods could begin reproduction almost immediately once an adequate temperature is reached.

Pseudoisochrysis sp. and Prorocentrum marieaelebouriae appear to be adequate foods for reproduction by Scottolana canadensis females. The average brood size at $25^{\circ} \mathrm{C}$ of $18.9 \pm 4.4$ (S.D.) nauplii per brood (Table 2) was not significantly different from that reported by Harris (1977; refer to Table 2) of $21.82 \pm$ 7.7 eggs per brood at $25{ }^{\circ} \mathrm{C}$ and $10 \% \mathrm{~S}$ when fed a diet of Isochrysis galbana and Thalassiosira pseudonana $(0.20<\mathrm{p}<0.30$; t-test for differences between means). In addition, the brood sizes were not significantly different $(0.10<p<0.20)$ from gravid females taken from the field in the summer months $\left(\cong 25^{\circ} \mathrm{C}\right)$ which were found to average $26.0 \pm 6.8$ eggs per brood (Lonsdale,
1981). However, food quality may have influenced lifetime fecundity. I calculated the average number of broods produced by $S$. canadensis to be $12.1 \pm 5.6$ from data reported by Harris (1977; refer to Table 1). While in this study an average of $6.8 \pm 3.1$ broods was calculated for females under a similar temperature and salinity regime (Table 2 ).

In the laboratory the sex ratio of Scottolana canadensis appeared to approximate $1: 1\left(1.3 \%\right.$ ㅇ 1 o t at $20^{\circ} \mathrm{C}$, $0.89 \$: 10^{\circ}$ at $25^{\circ} \mathrm{C}$ ). The intrinsic rate of population increase, $r$, was calculated using the experimental survivorship curves and fecundity schedules based upon the observed sex ratio (Table 2 ). The greatest value ( $r$ $=0.13 \mathrm{~d}^{-1}$ ) was observed at $25^{\circ} \mathrm{C}$ and $10 \% \mathrm{~S}$. All other values ranged between $0.08-0.05 \mathrm{~d}^{-1}$. The $r$ values also were calculated using a fecundity schedule which assumed a 1:1 sex ratio. Only the $r$ estimate at $25{ }^{\circ} \mathrm{C}$ and $15 \% \mathrm{~S}\left(r=0.10 \mathrm{~d}^{-1}\right)$ and at $20{ }^{\circ} \mathrm{C}$ and $10 \% \mathrm{~S}\left(r=0.07 \mathrm{~d}^{-1}\right)$ were affected because actual sex ratios had shown the greatest deviation from 1:1.

On the premise that nauplius mortality was unnaturally high in the laboratory at $25^{\circ} \mathrm{C}$, a third series of $r$

Table 2. Scottolana canadensis. Intrinsic rate of population increase, survival and reproductive statistics at different temperatures and salinities

\begin{tabular}{|c|c|c|c|c|c|c|c|c|}
\hline \multirow[t]{2}{*}{$\begin{array}{c}\text { Temperature } \\
\left({ }^{\circ} \mathrm{C}\right)\end{array}$} & \multirow[t]{2}{*}{$\begin{array}{l}\text { Salinity } \\
(\% \infty)\end{array}$} & \multirow[t]{2}{*}{$\begin{array}{l}\text { Day of first } \\
\text { reproduction }\end{array}$} & \multirow{2}{*}{$\begin{array}{c}\% \text { survival } \\
\text { of nauplii } \\
\text { to adult }\end{array}$} & \multirow[t]{2}{*}{$\begin{array}{c}r \\
\left(d^{-1}\right)\end{array}$} & \multirow[t]{2}{*}{ 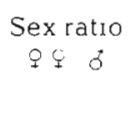 } & Brood size & $\begin{array}{l}\text { Number of } \\
\text { broods }\end{array}$ & \multirow[t]{2}{*}{$\begin{array}{c}r\left(\mathrm{~d}^{-1}\right) \\
\text { sex ratio } \\
1 \&: 10\end{array}$} \\
\hline & & & & & & S.D. & $\bar{X} \quad$ S.D. & \\
\hline \multirow[t]{3}{*}{25} & 10 & 13 & 59 & 0.13 & $0.99: 1$ & $13.4 \pm 8.7$ & $6.8 \pm 3.1$ & $0.13^{\bullet}$ \\
\hline & 1.5 & 17 & 42 & 0.07 & $0.53: 1$ & $24.2 \pm 13.4$ & $6.8 \pm 5.0$ & 0.10 \\
\hline & 20 & 19 & 40 & 0.06 & $1.16: 1$ & $19.2 \pm 11.8$ & $6.0 \pm 2.9$ & 0.06 \\
\hline \multirow[t]{3}{*}{20} & 10 & 26 & 72 & 0.08 & $1.37: 1$ & $14.9 \pm 9.5$ & $4.0 \pm 2.2$ & 0.07 \\
\hline & 15 & 23 & 67 & 0.05 & $1.34: 1$ & $14.1 \pm 11.1$ & $4.2 \pm 3.2$ & 0.05 \\
\hline & 20 & 27 & 41 & 0.06 & $1.20: 1$ & $22.4 \pm 10.3$ & $6.1 \pm 4.0$ & 0.06 \\
\hline
\end{tabular}


values was calculated by adjusting survivorship upward to 0.83 on Day 6 (Heinle, unpubl.). The $r$ values at $25^{\circ} \mathrm{C}$ and 10 and $15 \%$ S increased by $0.01 \mathrm{~d}^{-1}$ and $0.03 \mathrm{~d}^{-1}$ at $20 \% \mathrm{~S}$. Salinity appears to effect the survivorship of nauplii and copepodites of Scottolana canadensis and thus this latter increase may be an overestimate.

An estimate of $r$ also was obtained applying the fecundity statistics of Harris (1977) (mean brood size = 21.8 eggs per brood and mean number of broods $=12$ ) and survivorship data from my studies. Assumptions were made that (1) the females produced broods at equal intervals throughout their lifespan (ranging from 57-84 d; data from Harris); (2) the days of first reproduction (nauplii hatched) were equivalent to those in my studies (Days $13-16$ at $25^{\circ} \mathrm{C}$ and $10 \% \mathrm{~S}$ ); and (3) all eggs successfully hatched into nauplii. The $r$ value obtained was $0.15 \mathrm{~d}^{-1}$, an increase of $0.02 \mathrm{~d}^{-1}$ at $25^{\circ} \mathrm{C}$ and $10 \% \mathrm{~S}$. I also estimated $r$ to be $0.17 \mathrm{~d}^{-1}$ using other fecundity statistics reported by Harris (1977; Table 1); mean brood sizes ranged from 24,9-35.5 eggs. These latter rates may be overestimates if all eggs did not successfully hatch, a phenomenon I have frequently observed.

\section{Oithona colcarva: Survivorship and Reproduction}

The survival of Oithona colcarva from Day 0 (day of hatching) through adult was lowest at $15^{\circ} \mathrm{C}$ where only $13 \%$ survived to reproductive maturity (Fig. 3 ). Maximum longevity observed was Day 81 at $15^{\circ} \mathrm{C}$, Day 53 at $20^{\circ} \mathrm{C}$ and Day 39 at $25^{\circ} \mathrm{C}$. High mortality occurred in $O$. colcarva during the metamorphic change from NVI to Cl. Mortality was low in the later copepodite stages and through the major portion of the adult reproductive stage. Possibly this poor survival indicates that further improvement in culturing technique is needed. However, high mortality at the NVI-CI molt has been reported in other laboratory experiments (Harris and Paffenhöfer, 1976), as well as in the field (Rigler and Cooley, 1974), and so these results may not be an unusual natural occurrence.

The mean day of first reproduction of Oithona colcarva was 18.0 at $20^{\circ} \mathrm{C}$ and 11.7 at $25^{\circ} \mathrm{C}$. The fecundity of $O$. colcarva may have been seriously affected by food quality. At $25^{\circ} \mathrm{C}$, in the laboratory the average number of nauplii which hatched per brood (10.5 \pm 9.0) was significantly different ( $p<0.005$ ) from the brood size collected in the field $(16.8 \pm 3.7$ eggs per brood) at approximately $25^{\circ} \mathrm{C}$ (Lonsdale, 1981). At $20^{\circ} \mathrm{C}$, the difference between brood size determined in the laboratory ( $6.1 \pm 4.2$ nauplii per brood) and that in the field (20.0 \pm 4.2 eggs per brood) also was significant $(\mathrm{p}<0.005$ ). Although only 30 . colcarva egg sacs
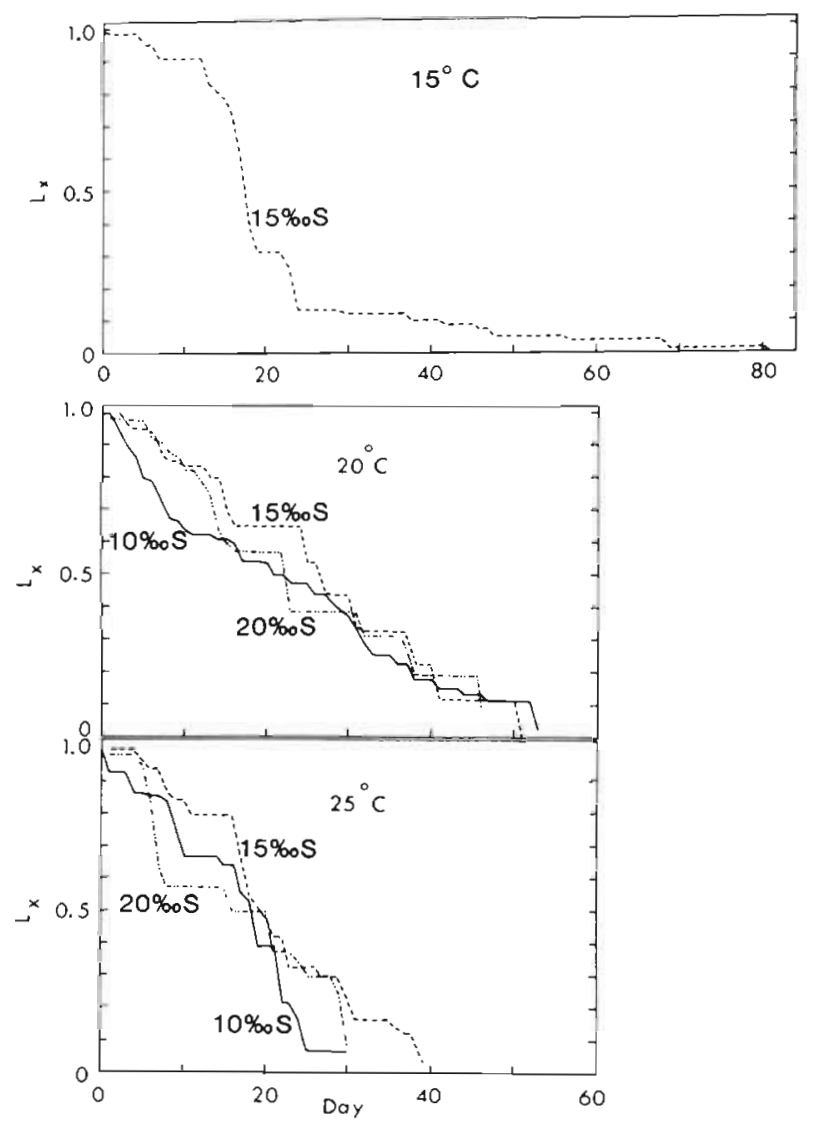

Fig. 3. Oithona colcarva. Survival in the laboratory from day of hatching through reproductive-female stage, at $15^{\circ}, 20^{\circ}$, and $25^{\circ} \mathrm{C}$ and in 3 different salinities

were found at $15^{\circ} \mathrm{C}$ for all samples counted, the data suggest that there may be significant differences in brood size between the laboratory populations and those in the field $(8.2 \pm 9.9$ versus $15.0 \pm 2.4$, respectively). It appears that $r$ may have been underestimated due to these differences. Using the average field fecundity and assuming that each brood produced in the laboratory resulted in an equivalent number of viable NI, I calculated an increase in $r$ ranging from $0.01-0.05$ $\mathrm{d}^{-1}$ (Table 3). The lowered egg production of $O$. colcarva in the laboratory could have been due to the absence of animal prey (i.e. ciliates, rotifers or copepod nauplii) in the diet as it is probable that this cyclopoid copepod is omnivorous (Lampitt, 1978).

Estimates of brood sizes in the laboratory (nauplii per brood) and field (eggs per brood) may not be

\footnotetext{
- The value of 16.8 eggs per brood is based on the number of eggs counted per individual sac, $8.4 \pm 1.9$, multiplied by 2 . Many of the egg sacs had been separated from gravid females in preserved field samples as females will drop their eggs when treated with formalin. Healthy females in the laboratory usually carry two sacs and I presumed that this was true for females in the field
} 
directly comparable for 2 reasons. First, not all eggs carried by females in the laboratory produced viable nauplii; this may also apply to eggs carried by females in the field. Second, values for brood size in the laboratory represent averages over the entire life span of the females. The average number of nauplii hatched was sometimes higher in the first few weeks of reproduction than later. For example, at $20^{\circ} \mathrm{C}$ and $20 \% \mathrm{~S}$, the number of Oithona colcarva nauplii hatched per brood averaged $12.4 \pm 6.3$ during the first week and only $3.5 \pm 1.5$ for the remainder of the experiment. Egg sacs carried by females in the field may represent first or second broods if adult mortality is high. Although this latter point may be important for comparing laboratory and field brood sizes and thus in assessing diet inadequacies, it was of lesser importance in influencing $r$. I calculated an increase of $0.01 \mathrm{~d}^{-1}$ at $20^{\circ}$ and $20 \% \mathrm{~S}$ when the number of nauplii hatched per brood in the second week was assumed equivalent to that during the first week (12.4 nauplii per brood).

The average sex ratio of Oithona colcarva offspring was 5.4 $q q: 1$ of for all experiments combined. This skewed sex ratio is similar to that observed in natural populations (6.8 $q$ : 1 i $\delta$; personal observation). Therefore, $r$ was determined using only the observed sex ratio for calculating the number of female births. The intrinsic rate of population increase of $O$. colcarva was greater at higher temperatures and salinities (Table 3).

\section{DISCUSSION}

The rates of population increase $(r)$ obtained for both Scottolana canadensis and Oithona colcarva were lower at all temperatures than those reported for other estuarine copepods; e.g. Gladioferens imparipes 10.146 and $0.293 \mathrm{~d}^{-1}$ at $15^{\circ}$ and $25^{\circ} \mathrm{C}$, respectively; Rippingale and Hodgkin, 1974) and Acartia tonsa (>0.23-0.25 $\mathrm{d}^{-1}$ at $20^{\circ} \mathrm{C}$; Heinle, unpubl.) or of predicted ranges for copepods made by Allan and Goulden $(1980 ; 0.28-0.40$ $\mathrm{d}^{-1}$ at $25^{\circ} \mathrm{C}$ ). The discrepancies between these values can be due only in part to juvenile mortality or inadequate food quality in my study. Hence, they must reflect real differences between the species. Some factors which contribute to differences in $r$ between $A$. tonsa and both $S$. canadensis and $O$. colcarva are differences in growth rate and development time of eggs (Table 4). At $20^{\circ} \mathrm{C}$, A. tonsa will develop at the

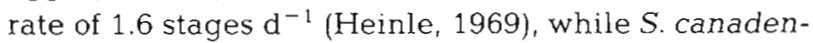

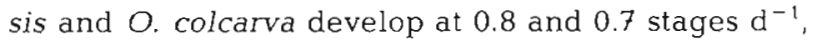
respectively. These results also are consistent with McLaren's (1978) observation that the two smallest copepods in Loch Striven, Scotland have the longest generation times. A. tonsa is the largest of the 3 , with adult females averaging $1.25-1.5 \mathrm{~mm}$ in total length (Wilson, 1932). Adult females of $S$. canadensis average $0.96-1.21 \mathrm{~mm}$, and $O$. colcarva average $0.65-0.77 \mathrm{~mm}$ (Wilson, 1932; Coull, 1972). A. tonsa eggs begin to hatch $20-22 \mathrm{~h}$ after being laid at $18^{\circ} \mathrm{C}$ (Parrish and Wilson, 1978) while eggs of $S$. canadensis take $104 \mathrm{~h}$ and those of $O$. colcarva 46 h at $20^{\circ} \mathrm{C}$ (Lonsdale, 1981).

Life history statistics of Scottolana canadensis, Oithona colcarva (this study), and Acartia tonsa (Parrish and Wilson, 1978) may reflect important changes in the selective forces operating during their respective life spans as the result of differences in adult habitat. Nauplius development of $S$. canadensis occurs in the upper layers of the water column of the Chesapeake Bay, and, upon metamorphosis to Copepodite I-II, individuals descend and maintain an epibenthic existence through the adult reproductive life. Scottolana populations may experience low mortality of adult stages relative to the planktonic nauplii owing to their epibenthic habitat which may serve as a refuge from visual predators (Allan, 1978). In contrast the totally planktonic Acartia spp., and $O$. colcarva in this study, may be subject to variable heavy predation on the larger, later stages (Miller et al., 1977).

Laboratory and field data provide evidence which suggests that the proposed pattern of differential survi-

Table 3. Oithona colcarva. Intrinsic rate of population increase, survival and reproductive statistics at different temperatures and salinities

\begin{tabular}{|c|c|c|c|c|c|c|c|}
\hline $\begin{array}{c}\text { Temperature } \\
\left({ }^{\circ} \mathrm{C}\right)\end{array}$ & $\begin{array}{l}\text { Salinity } \\
(\% \circ)\end{array}$ & $\begin{array}{l}\text { Day of first } \\
\text { reproduction }\end{array}$ & $\begin{array}{l}\% \text { surviva! } \\
\text { of nauplii } \\
\text { to adult }\end{array}$ & $\begin{array}{c}r \\
\left(d^{-1}\right)\end{array}$ & $\begin{array}{l}\text { Sex ratio } \\
99: \delta\end{array}$ & $\begin{array}{l}\text { Brood size } \\
\bar{X} \quad \text { S.D. }\end{array}$ & $\begin{array}{c}r\left(d^{-1}\right) \\
\text { using field } \\
\text { brood sizes }\end{array}$ \\
\hline 25 & $\begin{array}{l}10 \\
15 \\
20\end{array}$ & $\begin{array}{l}13 \\
12 \\
10\end{array}$ & $\begin{array}{l}66 \\
80 \\
58\end{array}$ & $\begin{array}{l}0.08 \\
0.16 \\
0.13\end{array}$ & $\begin{array}{l}5.3 \cdot 1 \\
6.0 \cdot 1 \\
4.7: 1\end{array}$ & $\begin{array}{r}15.8 \pm 7.1 \\
13.6 \pm 12.7 \\
7.6 \pm 4.3\end{array}$ & $\begin{array}{l}0.11 \\
0.19 \\
0.18\end{array}$ \\
\hline 20 & $\begin{array}{l}10 \\
15 \\
20\end{array}$ & $\begin{array}{l}18 \\
18 \\
18\end{array}$ & $\begin{array}{l}54 \\
65 \\
58\end{array}$ & $\begin{array}{l}0.06 \\
0.08 \\
0.10\end{array}$ & $\begin{array}{l}5.4: 1 \\
5.4: 1 \\
5.5: 1\end{array}$ & $\begin{array}{l}5.2 \pm 7.8 \\
6.3 \pm 2.9 \\
9.6 \pm 6.9\end{array}$ & $\begin{array}{l}0.11 \\
0.13 \\
0.13\end{array}$ \\
\hline 15 & 15 & 29 & 13 & 0.001 & $5.4: 1$ & $8.2 \pm 9.4$ & 0.01 \\
\hline
\end{tabular}


Table 4. Life-history traits of Acartia tonsa (at $18^{\circ} \mathrm{C}$ ) compared to Scottolana canadensis and Oithona colcarva (20 ${ }^{\circ} \mathrm{C}$ ). Data for A. tonsa from Heinle (unpubl.) and Parrish and Wilson (1978)

\begin{tabular}{|c|c|c|c|c|c|c|c|}
\hline Species & $r\left(d^{-1}\right)$ & $\begin{array}{c}\text { Egg hatching } \\
\text { time (h) }\end{array}$ & $\begin{array}{c}\text { Stages } \\
\mathrm{d}^{-1}\end{array}$ & $\begin{array}{c}\text { Lifetime } \\
\text { production } \\
\text { (per reproductive } \\
\text { female) }\end{array}$ & $\begin{array}{l}\text { Day of first } \\
\text { reproduction }\end{array}$ & $\begin{array}{l}\text { Reproductive } \\
\text { lifespan } \\
\text { (d) }\end{array}$ & $\begin{array}{c}\text { Egg } \\
\text { production }\end{array}$ \\
\hline A. tonsa & $>0.23-0.25$ & $20-22$ & 1.6 & 516 eggs & $7-9.0$ & 24.7 & continuous \\
\hline S. canadensis & $0.05-0.08$ & 104 & 0.8 & 80-165 nauplii & 25.3 & 62.0 & broods \\
\hline O. colcarva & $0.06-0.13$ & 46 & 0.7 & & 18.0 & 15.4 & broods \\
\hline
\end{tabular}

val of nauplii and adults may occur in the field. The nauplii of Scottolana canadensis are more susceptible to some sources of predation (from abundant planktonic invertebrates) than are their adults, and predation on the nauplii may be the primary regulating factor during the summer (Lonsdale, 1981). Moreover, in Chesapeake Bay, the diets of epibenthic feeding juvenile spot and bay anchovies are primarily composed of the large calanoid copepod Pseudodiaptomous coronatus while $S$. canadensis adults are rarely encountered (Homer and Boynton, 1978). Indirect evidence suggests that predation may be greater on the larger stages of Acartia tonsa; the instantaneous death rates for nauplii frequently are less than that for copepodites in both the Rhode River and Chesapeake Bay (Allan et al., 1976; Heinle et al., 1977; but see Heinle, 1966). Copepodite and adult mortality due to fish predation has been proposed to regulate the cycle of abundance of $A$. clausii in a small temperate lagoon (Landry, 1976). It is plausible that these patterns are the result of selection for Acartia adults by filter-feeding fish which demonstrate maximal filtering efficiency in the size range of the adults $(1.2-10 \mathrm{~mm}$; Durbin and Durbin, 1975) or by visual size-selective predators (Brooks and Dodson, 1965). Thus mortality of the adults would be greater than of either nauplii or copepodites. The susceptibility of $A$. tonsa adults to predation also is emphasized by the observation that they are more heavily preyed upon by ctenophores than are adults of either $S$. canadensis or Oithona colcarva (Lonsdale, 1981).

In a fluctuating environment where juvenile mortality is higher than that of adults, decreased reproductive effort, smaller clutches and a longer lifespan should be favored (Schaffer, 1974). A comparison of the life history characteristics of Scottolana canadensis, Oithona colcarva and Acartia tonsa lends support to these predictions (Table 4). At $18^{\circ} \mathrm{C}$ in culture, $A$. tonsa had an adult reproductive lifespan of approximately $26.2 \mathrm{~d}$ (24.7 $\mathrm{d}$ from the beginning of reproduction; Parrish and
Wilson, 1978) while at $20^{\circ} \mathrm{C}$ and $15 \% \mathrm{~S}$ the average adult mean reproductive lifespan of $S$. canadensis was $62 \mathrm{~d}$ and of $O$. colcarva, $15.4 \mathrm{~d}$. However, the day of first reproduction was much earlier for $A$. tonsa than for the other 2 species. The egg production pattern also differs among these species. A. tonsa produce eggs almost continuously while the other 2 species produce broods at discrete intervals: e.g. S. canadensis averaged one sac of eggs every $5.8 \pm 1.7 \mathrm{~d}$ at $20^{\circ} \mathrm{C}$ and $15 \% \mathrm{~S}$. Although this intermittent reproductive pattern is consistent with theoretical interpretations for variable juvenile survival, it also may be an adaptation for protection against egg predators. The delay between broods may reflect only the time necessary for many eggs to be produced, collected in a sac, and develop through hatching. There is evidence that $A$. tonsa eggs suffer constant heavy mortality by being released singly (Kimor, 1979).

These differences in the reproductive traits between Acartia tonsa and Scottolana canadensis are more striking than the differences between $A$. tonsa and Oithona colcarva. The former 2 are more similar in size and yet there are differences in day of first reproduction, pattern of brood production and total reproductive life span. This marked difference in reproductive strategy seems best explained by the differences in age-specific mortality patterns which may exist between $A$. tonsa and $S$. canadensis. Due to the fact that predation on the nauplii at times is the most important source of mortality to $S$. canadensis, their reproductive traits may be the result of a trade-off in energy resources in order to increase adult survival and thereby lengthen the time period over which nauplii could be produced. This would enhance fitness in an unpredictable environment by spreading the risk of nauplius mortality over time. In contrast, the reproductive traits of $A$. tonsa may be the result of less energy being devoted to adult maintenance and more to immediate reproduction, in an environment where the predation risk to adults is very high. 
Acknowledgements. I thank J. D. Allan, D. Bonar, P. Donaghay, D. R. Heinle, C. B. Miller, D. Morse, and M. Reaka for preliminary discussions and critical reviews of this manuscript. Research facilities and laboratory equipment were provided by the Chesapeake Biological Laboratory and the Department of Zoology of the University of Maryland. This research was supported by a fellowship from the Center for Environmental and Estuarine Studies, and funding from the Department of Zoology, and the Chesapeake Bay Fund at the University of Maryland.

\section{LITERATURE CITED}

Allan, J. D. (1976). Life history patterns in zooplankton. Am. Nat. 110: 165-180

Allan, J D. (1978). Trout predation and the size composition of stream drift. Limnol. Oceanogr. 26: 1231-1237

Allan, J. D., Goulden, C. E. (1980). Some aspects of reproductive variation among freshwater zooplankton. In: Kerfoot, C. W (ed.) The evolution and ecology of zooplankton communities. Am. Soc. Limnol. Oceanogr. Spec. Symposium

Allan, J. D., Kinsey, T. G., James, M. C. (1976). Abundances and production of copepods in the Rhode River subestuary of Chesapeake Bay. Chesapeake Sci. 17: 86-92

Birch, L. C. (1948). The intrinsic rate of natural increase of an insect population. J. Anim. Ecol. 17: 15-26

Brooks, J. L., Dodson, S. I. (1965). Predation, body size and composition of plankton. Science, N.Y. 150: 28-35

Charnov, E. L., Schaffer, W M. (1973). Life history consequences of natural selection: Cole's result revisited. Am. Nat. 107: 791-793

Coull, B. C. (1972). Scottolana canadensis (Willey, 1923) (Copepoda, Harpacticoida) redescribed from the United States East Coast. Crustaceana 22: 209-214

Durbin, A. G., Durbin, E. G. (1975). Grazing rates of the Atlantic menhaden Brevoortia turannos as a function of particle size and concentration. Mar. Biol. 33: 265-277

Gadgil, M., Bossert, W. (1970). Life history consequences of natural selection. Am. Nat. 104: 1-24

Harris, R. P. (1977). Some aspects of the biology of the harpacticoid copepod, Scottolana canadensis (Willey), maintained in laboratory culture. Chesapeake Sci. 18: 245-252

Harris, R. P., Paffenhöfer, G. A. (1976). Feeding, growth and reproduction of the marine planktonic copepod Temora longicornis Muller. J. mar. biol. Ass. U.K. 56: 675-690

Heinle, D. R. (1966). Production of a calanoid copepod, Acartia tonsa, in the Patuxent River Estuary. Chesapeake Sci. $7: 59-74$

Heinle, D. R. (1969). Temperature and zooplankton. Chesapeake Sci. 10: 186-209

Heinle, D. R., Millsaps, H. S., Millsaps, C. V. (1977). Effects of tropical storm Agnes on standing crops and age structure of zooplankton in middle Chesapeake Bay. Chesapeake Research Consortium No. 54: 443-459
Homer, M., Boynton, W (1978). Stomach analysis of fish collected in the Calvert Cliffs region. Chesapeake Bay 1977. Final Report to Maryland Department of Natural Resources Power Plant Siting Program, CBL Ref. No. $78-154,306 \mathrm{pp}$

James, D. E. (1973). Culturing algae in the classroom, p. 1-35. In Symposium on teaching with algae. $24^{\text {th }}$ Annual AlBS Meeting. Carolina Biological Supply Co. North Carolina

Kimor, B. (1979). Predation by Noctiluca miliaris Souriray on Acartia tonsa Dana eggs in the inshore waters of southern California. Limnol. Oceanogr. 24: 568-572

Lampitt, R. S. (1978). Carnivorous feeding by a small marine copepod. Limnol. Oceanogr. 23: 1228-1230

Landry, Mr. R. (1976). Population dynamics of the planktonic marine copepod, Acartia clausi Giesbrecht, in a small temperate lagoon. Ph. D. thesis, University of Washington

Lonsdale, D. (1981). Regulatory role of physical factors and predation for two Chesapeake Bay copepod species. Mar. Ecol. Prog. Ser. 5: 341-351

McArthur, R. H. (1972). Geographical ecology - Patterns in the distribution of species, Harper and Row, New York

McLaren, I. A. (1963). Effects of temperature and growth of zooplankton, and the adaptive value of vertical migration. J. Fish. Res. Bd Can. 20: 685-727

McLaren, I. A. (1974). Demographic strategy of vertical migration by a marine copepod. Am. Nat. 108: 91-102

McLaren, I. A. (1978). Generation lengths of some temperate marine copepods: Estimation, prediction, and implications. J. Fish. Res. Bd Can. 35: 1330-1342

Miller, C. B., Johnson, J. K., Heinle, D. R. (1977). Growth rules in the marine copepod genus Acartia. Limnol. Oceanogr. 22: 326-335

Murphy, G. I. (1968). Pattern in life history and the environment. Am. Nat. 102: 391-403

Parrish, K. K., Wilson, D. F. (1978). Fecundity studies on Acartia tonsa (Copepoda: Calanoida) in standardized culture. Mar. Biol. 46: 65-81

Pianka, E. R., Parker, W S. (1975). Age-specific reproductive tactics. Am. Nat. 109: 453-464

Richman, S., Heinle, D. R., Huff, R. (1977). Grazing by adult estuarine calanoid copepods of the Chesapeake Bay. Mar. Biol. 42: 69-84

Rigler, F. H., Cooley, J. M. (1974). The use of field data to derive population statistics of multivoltine copepods. Limnol. Oceanogr 19: 636-655

Rippingale, R. J., Hodgkin, E. P. (1974). Population growth of a copepod Gladioferens imparipes Thomson. Aust. J. mar Freshwat. Res. 25: 351-360

Schaffer, W. M. (1974). Selection for optimal life histories: the effects of age structure. Ecology 55: 291-303

Stearns, S. C. (1976). Life history tactics: a review of the ideas. Q. Rev. Biol. 51: 3-47

Wilson, C. B. (1932). Copepods of the Woods Hole Region, Massachusetts. Smithsonian Institution U.S. National Museum Bu1l. 158. U.S. Government Printing Office. Washington, DC, $635 \mathrm{pp}$ 